\title{
Research on the Design of Experimental Teaching System for Applied Logistics Management Major
}

\author{
Xiaofen Zhou \\ Wuhan Technology And Business University \\ Wuhan, China
}

\author{
Rongyan Zhu \\ Wuhan Technology And Business University \\ Wuhan, China
}

\begin{abstract}
Compared with theoretical teaching, experimental teaching has the characteristics of high flexibility, diverse forms and rich resources. Establishing a reasonable and effective experimental teaching system is of great help to the application of logistics talents. This paper introduces the status of logistics management experiment teaching, the importance of experimental teaching system. It is proposed that the application of logistics talents should be guided by the needs of enterprise talents, deepen the cooperation between schools and enterprises, rationally use virtual simulation technology and enterprise resources, use the teaching team and enterprise faculty, establish a sound assessment system, and give full play to the important role of experimental teaching in personnel training.
\end{abstract}

Keywords-cultivation of talents; experimental; teaching system; logistics management;

Logistics management is a profession that requires students have strong practical ability. In order to cultivate the application-oriented logistics management talents, the private colleges should be oriented to the needs of the logistics industry, and a reasonable and effective teaching system should be set up. The design of the experimental teaching system that can combine theory with practice is particularly important. In order to cultivate applied logistics talents, the design of experimental teaching curriculum system should be based on the core theory and key- business processes of modern logistics industry, guided by ability training, follow the scientific and practical principles of logistics experiment teaching, and play an important role in logistics experiment teaching.

\section{ANALYSIS OF THE EXPERIMENTAL TEACHING STATUS OF LOGISTICS MANAGEMENT}

Emphasis on teaching reform of university education increases every year, but in the reform process, due to various constraints, the cultivation of logistics management talents still attaches importance to theoretical teaching and neglects experimental teaching. Some colleges aiming at cultivating applied talents have gradually attached importance to experimental teaching, but the students who are trained still have a large gap with the demand for logistics management undergraduate talents. The combination of teaching and practice needs to be further strengthened.

Fund project: Wuhan Technology And Business University 2017 School Teaching Reform Project (2017Z03); 2018 Experimental Teaching and Cultivation Project (2018KC05).
In-depth analysis of experimental teaching content design, teaching methods, teaching conditions, assessment methods and teaching system construction, there is still a certain gap with actual needs. From the perspective of experimental teaching content design, the experimental content is rigid, mainly based on traditional cognitive internship, professional curriculum design, graduation design and graduation internship; from the perspective of teaching methods, demonstrations, cases, software simulation, writing reports, etc. [1]. Mainly, from the perspective of teaching conditions, the laboratory functions of each institution are single, and most laboratories can only be used to observe. From the perspective of experimental assessment, the assessment objectives are not targeted, the assessment measures are not standardized, and the practice teaching assessment is generally lower than the assessment of theoretical teaching. From the perspective of teaching system construction, the arrangement and design of experimental teaching content is not systematic, Reasonable utilization of experimental resources is poor.

\section{THE IMPORTANCE OF EXPERIMENTAL TEACHING IN LOGISTICS MANAGEMENT}

The economic development has brought about the rapid development of the logistics industry and increased the demand for logistics talents. From the perspective of employment in logistics management, the main focus is on the procurement, warehousing, distribution, transportation, planning and other related work content [2]. From this point of view, the logistics management work is systematic, with many links, complicated processes and high technology content. To cultivate the talents who can adapt to the needs of the logistics enterprises, we must pay attention to the cultivation of students' practical ability [3]. In the teaching process, the opportunities and time for students to practice in the enterprise are limited. Using enterprise practice and school resources, rationally designing experimental teaching system, giving full play to the role of experimental teaching, and achieving seamless connection between talent training and enterprise needs are important criteria for measuring the quality of experimental teaching.

\section{DESIGN OF EXPERIMENTAL TEACHING SYSTEM FOR APPLIED LOGISTICS MANAGEMENT MAJOR}

In the design of applied logistics management, the experimental teaching should combine the characteristics of logistics activities, coordinate experimental teaching and 
theoretical teaching, and solve the contradiction between experimental teaching environment and real environment. The design of experimental teaching system for logistics management should be guided by ability training, aim at cultivating students' comprehensive quality and satisfying the individual needs of enterprises, adhere to the principles of systemic, practical and cutting-edge, rational planning and design experimental teaching system [4]. Allowing students to master the basic operations of logistics during college, and improve their overall quality, stimulate students' potential as management talents, effectively solve the employment needs of enterprises, and improve student competitiveness. The design of experimental teaching system for applied logistics management major, which should be combined the needs of enterprises, the use of school and enterprise resources, stratified training and joint evaluation of schools and enterprises.

\section{A. Designing an Experimental Teaching System based on the Needs of Enterprise Logistics Talents}

Defining the training objectives of applied logistics talents is the primary factor in the design of experimental teaching systems. The experimental teaching system should focus on the goal of talent training, rational allocation of experimental teaching content and teaching resources, and complementing the theoretical teaching system. It is an inseparable whole with the theoretical teaching system. The application of experimental logistics teaching system design can make up for the limitations of theoretical teaching in time and space, and give full play to the diversity and flexibility of experimental teaching. It is guided by the needs of enterprise logistics talents, combined with the school orientation. Industry and regional characteristics, determine the employment direction of logistics major students, school-enterprise cooperation to develop students' professional ability training standards, jointly develop training programs for applied logistics talents, and rationally design experimental teaching systems for applied logistics talents.

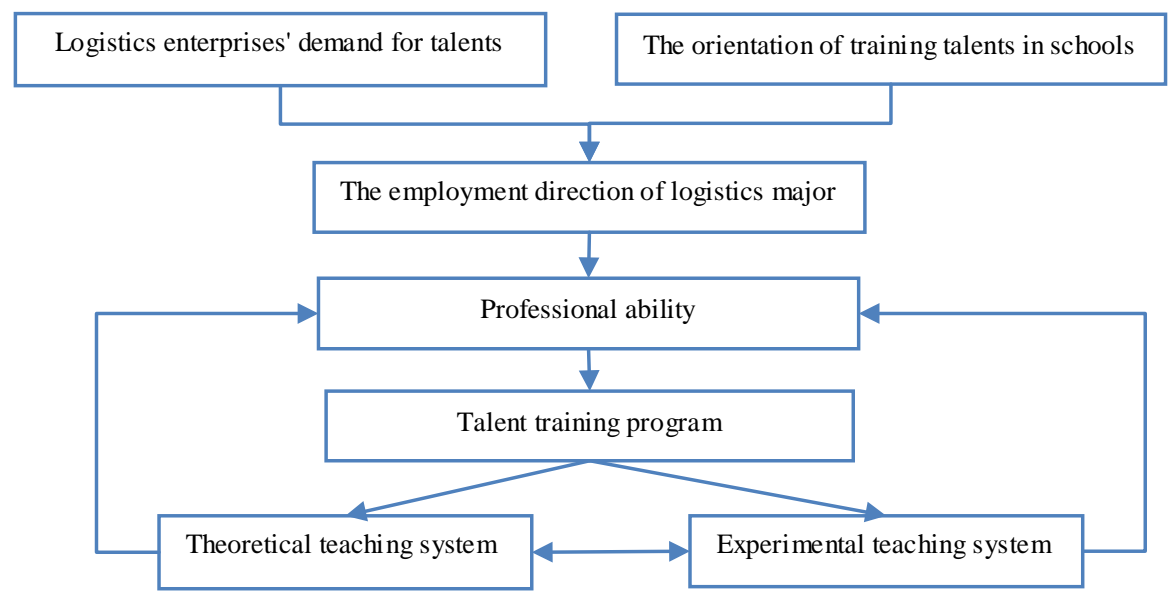

Fig. 1. The construction idea of talent training program

\section{B. Establish and Improve the Virtual Simulation Experiment System and Enterprise Practice Links}

The virtual simulation experiment teaching can better solve the conflict between the experimental teaching environment and the real environment, and rationally design and develop the virtual simulation experiment system, which greatly promotes the ability training of applied logistics management students [5]. The virtual simulation experiment teaching system aims at cultivating the ability of applied logistics talents, and through the $2 \mathrm{D}$ form, the operation ability of the general logistics system is cultivated. In the form of $3 \mathrm{D}$ virtual simulation, the training of logistics practical skills and operational management capabilities such as high cost and high risk is carried out; the practical skills of the enterprise post-training practice and the individualized ability to adapt to the needs of the enterprise are cultivated. At the same time, combined with the needs of enterprises and the needs of experimental courses, during the peak period of enterprise employment, such as "Double 11" and "718" activities, students are arranged to go deep into the enterprise practice, embedding the student's enterprise internship into daily experimental teaching and deepening enterprise cooperation. Realizing the seamless connection between the needs of enterprise users and the cultivation of talents in colleges.

\section{Designing Experimental Teaching System and Content by Stratification}

The ability of applied logistics management talents should be between academic and operational talents, as shown in Fig.2. Applied logistics talents not only have certain theoretical knowledge, but also have certain practical operation skills. Application-oriented talents can accurately grasp the causes, development and evolution of actual problems through the study of theoretical knowledge, and quickly find ways to solve problems. At the same time, they must master the basic operational procedures of all aspects of logistics activities and logistics systems. 


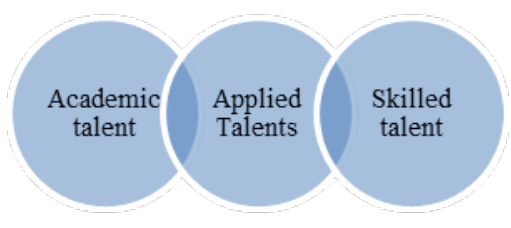

Fig. 2. The relationship between academic, skill and applied talents
Combining the requirements of academic and skilled talents for capacity development, it is concluded that applied logistics management talents must possess cognitive, control, design, collaboration and innovation capabilities. There are hierarchical relationships between these five capabilities, and the various levels and capabilities are shown in Fig.3.

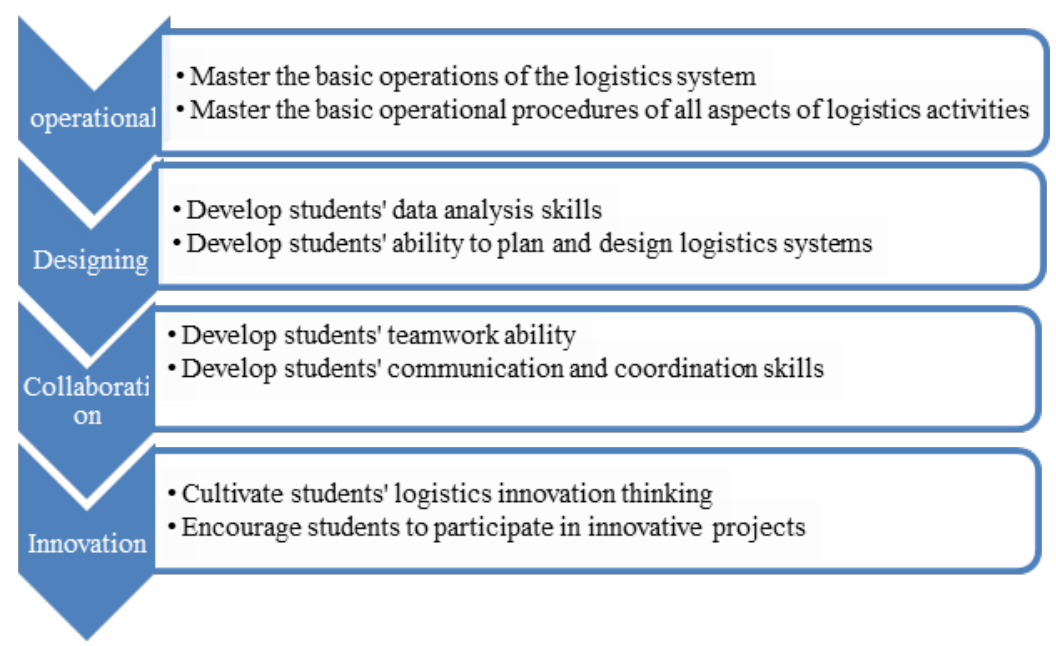

Fig. 3. Application-oriented logistics talent capacity hierarchy structure and requirements

From the perspective of teaching, ability training is a process from shallow to deep, step by step, and different levels of experimental content should be designed at different stages. Basic operation ability level training can open professional courses such as "Introduction to Professionals", "Introduction to Logistics Management", "Logistics Technology and Equipment", The practical operation ability of the students and the operation ability of the logistics system are cultivated by combining the on-site teaching of the logistics enterprise and the content of the verification experiment in the school. The course of operational ability is to set up "Distribution Center", "Purchasing Management", "Third-Party Logistics", etc. The experimental class accounts for more than $1 / 3$ of the total class hours, and open independent experiments of various practical courses, through the on-site teaching and internships. The Design Competency Course provides "Logistics System Planning and Design" and "Supply Chain Management". This type of course sets up in-class experiments to assist students in understanding theoretical knowledge. Schools and enterprises jointly set up course internships, allowing students to in-depth corporate internships, using the theoretical knowledge they have learned, analyzing and solving the basic problems of business operations management, cultivating students' design capabilities, and enhancing students' analytical and operational management capabilities. In the process of cultivating interdisciplinary ability and design ability and innovation ability, in the design and arrangement of experimental teaching content, the experimental course is carried out in the form of project system, and the students' team consciousness and coordination ability are cultivated. Innovative ability training encourages students to participate in professional and creative innovation projects.

\section{Set Up a Good Experimental Course Evaluation System}

The examination of experimental courses has always been a serious neglect in experimental teaching. It is generally only used as part of the usual grades. The assessment results are not separately recorded in the student's curriculum transcript. Therefore, it is impossible to get enough attention from students and teachers, which makes the experimental teaching limited to supplementing by theoretical teaching and cannot play its due role. In order to form an effective experimental teaching system, in addition to setting up a perfect experimental teaching system and novel, advanced and effective teaching methods, it is necessary to form an effective evaluation system for experimental teaching courses.

The teaching evaluation system of the experimental course should be adapted to the goal of application-oriented talent training, oriented to the needs of social talents, paying attention to the assessment of students' professional knowledge learning ability and vocational skills. Schools and enterprises jointly develop an assessment system for students' various abilities. At the same time, according to the individual characteristics of the students, personalized evaluation is given to better stimulate students' interest in experimental teaching and the cultivation of their own abilities, and achieve good results in experimental teaching[6]. At the same time, personalized evaluation based on student characteristics, which is better to stimulate students' interest in experimental teaching and the cultivation of their 
own abilities, and achieve good results in experimental teaching.

\section{SUMMARY}

The cultivation of applied logistics talents should closely integrate the needs of enterprises, deepen the road of schoolenterprise cooperation, and consolidate the needs of different enterprises into specific professional capabilities. Guided by professional competence, the design of a highly feasible experimental teaching system links teaching with corporate talent needs. In addition to clarifying the training objectives of experimental teaching, the design of experimental teaching system also needs to combine the resources inside and outside the school in the teaching process, give full play to the role of the teaching team and the enterprise, and carefully design the experimental content, experimental time, experimental teaching method of each experimental project. In the process of experimental learning, students will consolidate the basic knowledge that students learn in the theoretical curriculum, train students' basic operational skills, improve students' ability to analyze problems, solve problems and unite and cooperate. There is a "high-speed road" for students to enter the society from the school, which plays a substantial role in the cultivation of applied talents.

\section{REFERENCES}

[1] Shuxia Yan, Wanhua Liang, Discussion of the Experimental Teaching Mode of Logistics Management, Logistics Technology, 2012, pp.405407.( In Chinese).

[2] Ailing Chen, Yanfang Luo, Research on Experiment Teaching System of Logistics Management Education Based on Integrated Experimental Platform, Logistics Engineering and Management, vol.39, 2017, pp.193194 (In Chinese).

[3] Zhichen GAO, Yanhong Shi, Inquiry into the integration and innovation of the compound experiment teaching system for logistics management specialty in universities, Laboratory Science, vol.16, 2013, pp.76-78( In Chinese).

[4] Geng Yong, Study on Simulation Experiment Teaching of Undergraduate Logistics Management Specialty, Logistics Technology, vol.34,2 012, pp.282-284.( In Chinese).

[5] Ji Zhou, Kai Wang, Xiulan Zhang, Cunwen Wang, The comparison between series and parallel: Integrated experimental teaching model for pharmaceutical engineering students based on criteria for accrediting engineering programs in China, Journal of Cleaner Production, vol.172, 2018, pp.4421-4434.

[6] Yafeng Liu, Yuanxi $\mathrm{Wu}$, Construction of virtual simulation experimental teaching system of life science and technology, Experimental Technology and Management, vol.32, 2015,pp.121-123. (In Chinese). 